\title{
症例報告
}

\section{非侵襲的レジストレーションを用いた光学式手術 ナビゲーションシステムのロ腔疾患治療への応用}

\section{Application of Optic Surgical Navigation System Using Non-invasive Registration for the Treatment of Oral Disease}

\author{
和田重人 (正会員 $)^{\mathrm{a} *}$, 古田 勲 ${ }^{\mathrm{a}}$, 井上さやか ${ }^{\mathrm{a}}$, 能登久美子 ${ }^{\mathrm{a}}$, アレクサンダー・シュラム ${ }^{\mathrm{b}}$, \\ ニルス・クラウディウス・ゲーリッヒ ${ }^{\mathrm{b}}$ ，ライナー・シュメルザイセン \\ a 富山大学医学部歯科口腔外科学講座 \\ b フライブルク大学歯学部学顔面外科学講座
}

Shigehito Wada ${ }^{\mathrm{a}}$, Isao Furuta ${ }^{\mathrm{a}}$, Sayaka Inoue ${ }^{\mathrm{a}}$, Kumiko Noto ${ }^{\mathrm{a}}$, Alexander Schramm ${ }^{\mathrm{b}}$, Nils-Claudius Gellrich ${ }^{\mathrm{b}}$, Rainer Schmelzeisen ${ }^{\mathrm{b}}$

${ }^{a}$ Department of Maxillofacial Surgery, Faculty of Medicine, University of Toyama.

${ }^{b}$ Department of Maxillofacial Surgery, Faculty of Dentistry, University of Freiburg.

\begin{abstract}
It is generally recognized that the optic surgical navigation system is a useful tool that provides accurate anatomical information in neurosurgery and orthopedic surgery. However, at present, this system is not used in maxillofacial surgery in Japan. We report a patient with postoperative maxillary cyst treated by cystectomy using an optical navigation system. A 68-year-old female visited our department due to swelling in the right maxillary area. CT scanning showed a cystic lesion extending from the maxillary tuberosity to the nasal cavity. The lesion was surgically resected using an optical navigation system. In this patient, the use of a navigation system allowed objective confirmation of the portion of the lesion close to the nasal cavity and that surrounding the root of the second molar. In the future, the optic navigation system is expected to become a useful tool for safe and accurate surgery by oral surgeons.
\end{abstract}

Key words:

Oral Surgery, Image-guided Surgery, Non-invasive Registration, Oral Disease.

\section{Introduction}

The surgical navigation system is a useful tool for visually recognizing surgical manipulation areas as 3-dimensional real-time images ${ }^{1-5)}$. In Japan, few cases of the

\footnotetext{
* 富山大学医学部歯科口腔外科学講座

テ 930-0194 富山市杉谷 2630

swada-tym@umin.ac.jp

受付 2006 年 3 月 28 日; 採択 2007 年 5 月 7 日
}

application of this system to the maxillofacial region have been observed in either reviews of the literature or reports in congresses. We report a patient with postoperative maxillary cyst treated by resection using an optical navigation system with non-invasive registration.

\section{Clinical case and methods}

Patient was a 68-year-old female, complaining the swelling in alveolus of the right maxillary labial gingiva. For past history, she had undergone surgery for empyema 
in the bilateral maxillary sinuses at the age of 19 years, for breast cancer at the age of 37 years, for cataract at the age of 62 years, and for renal cancer at the age of 64 years. There was no remarkable findings on family history. She had noticed swelling in the alveolus of the labial gingiva corresponding to the right maxillary molar when being in poor health 5-6 years earlier. In early December, 2004, she had a cold and developed swelling in the same area again. She visited a local otolaryngological hospital and was treated with an antibiotic. She was given an explanation of the association between the lesion and teeth in this hospital and voluntarily visited our department. General physical examination showed no special findings. Extraoral examination showed diffuse swelling from the right infraorbital region to the cheek. Intraoral examination revealed a soft elastic abscess-like swelling $(30 \times 30 \mathrm{~mm})$ with clear borders in the alveolus of the labial gingiva corresponding to the right maxillary second premolar and first molar. Palpation showed fluctuation and tenderness (Fig.

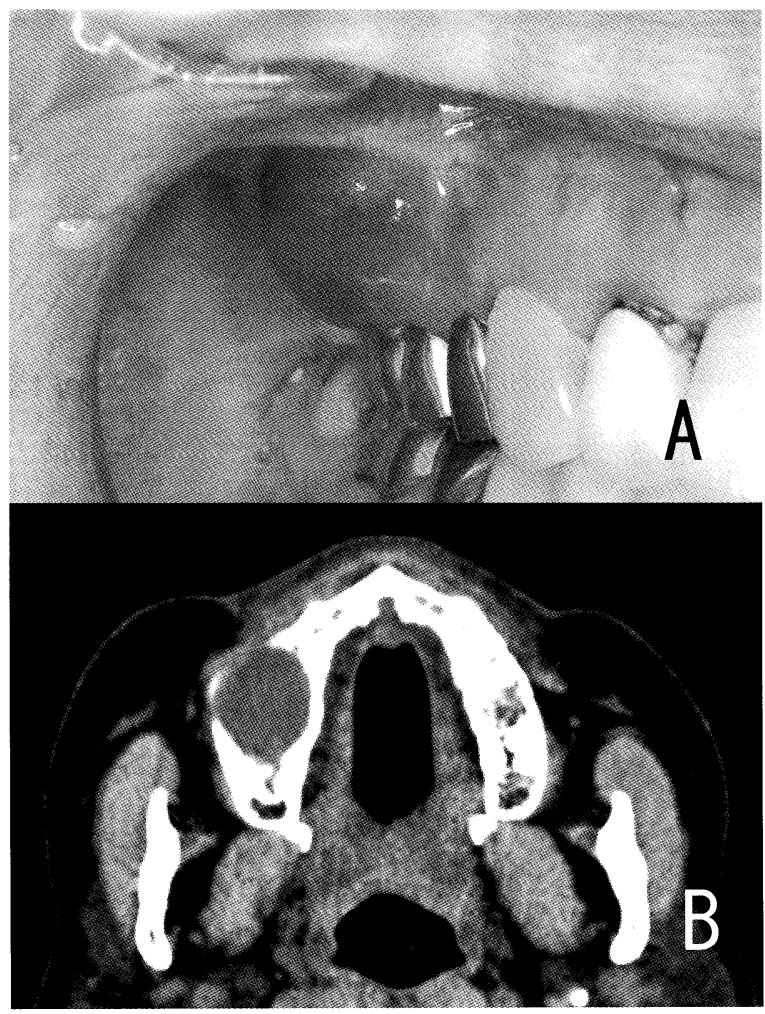

Fig. 1 Findings at initial consultation. A: Swelling was observed in the alveolus of the labial gingiva corresponding to the right maxillary molar. B: X-ray CT showed extension of a cyst-like translucency to the area surrounding the root of the second premolar.
1A). Tooth mobility was grade 3 for the right maxillary second premolar and first molar, and pain was observed on percussion. There were no sensory abnormalities in the facial skin, facial nerve paralysis, nor swelling/tenderness of the regional lymph nodes. Panoramic radiography showed a well-delineated unilocular cyst-like translucency from the alveolar bone to the maxilla corresponding to the right maxillary second premolar and first molar. The superior portion of the translucency appeared to be close to the nasal base. X-ray films for dental use revealed floating of the right maxillary second premolar. On X-ray CT scans, a quail egg-sized cyst-like translucency was observed in the right maxillary area, and the superomedial portion of the lesion was close to the nasal cavity while the posterior portion of the lesion extended to the area surrounding the dental root of the right second molar (Fig. 1B). Clinical diagnosis of right maxillary cyst (postoperative maxillary cyst) was made from these findings. On December 24, 2004, the abscess was incised under local anesthesia, and antibiotic treatment was initiated. The swelling had almost disappeared after about 1 week. For the use of a navigation system for resection of the maxillary cyst, consent was obtained from the patient after a detailed explanation. The explanation included that this system allows accurate surgical manipulation and safe surgery because the operation area can be objectively confirmed on images, the operation time is prolonged by about 1 hour due to setting of the apparatus and confirmation of its accuracy, and navigation is discontinued with priority being given to the operation when the planned operating time is expected to be further prolonged, or unexpected complications

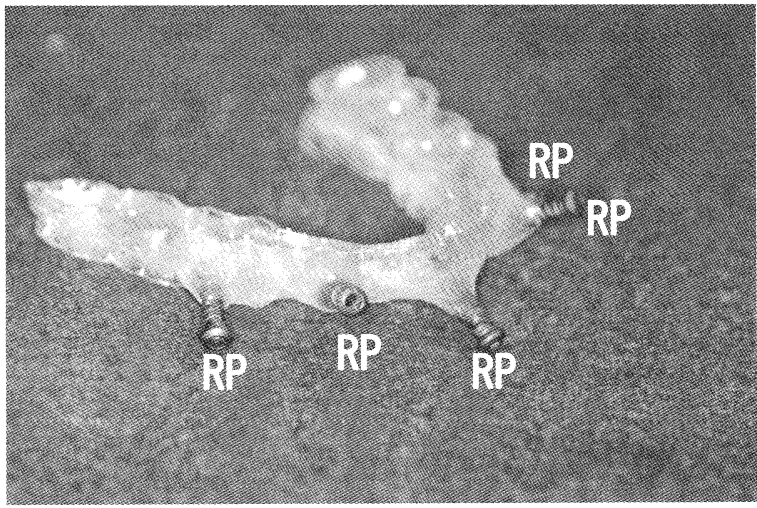

Fig. 2 Occlusal splint for registration. Five reference points (RP) were established using titanium screws for jaw facture. 


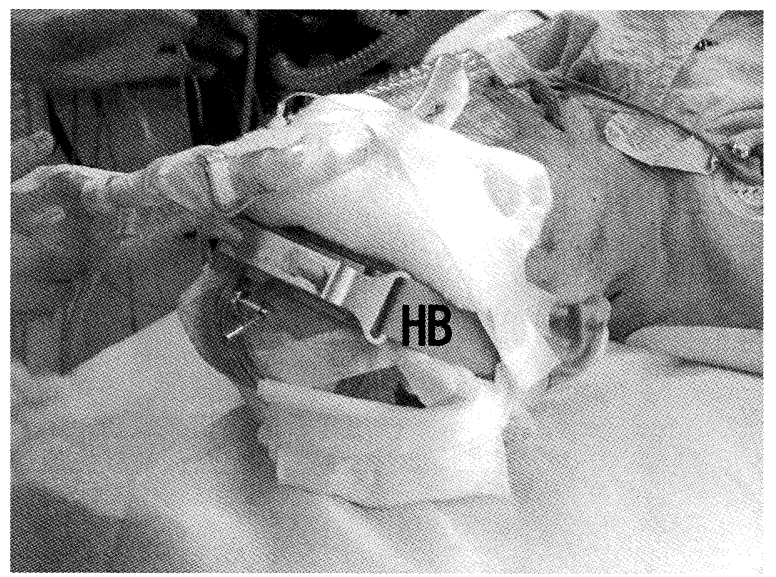

Fig. 3 Fixation of the headband. A firm fixation source was established using a special headband (HB) for the establishment of a patient tracker.

develop. For registration between the virtual space constructed by preoperative CT and the real space during operation, anatomical references (reference points) were established by fixing titanium screws for jaw fracture in a splint that fits the maxilla using quick cure resin (Fig. 2). With this split being applied to the maxilla, axial-X-ray CT from the orbital base to the hyoid bone was performed with a slice width of $1.0 \mathrm{~mm}$. The obtained navigation data were installed into a Stryker Navigation System (Model No. 6000-200-000; Stryker-Leibinger Co., Freiburg, Germany) before surgery, and 3-dimensional

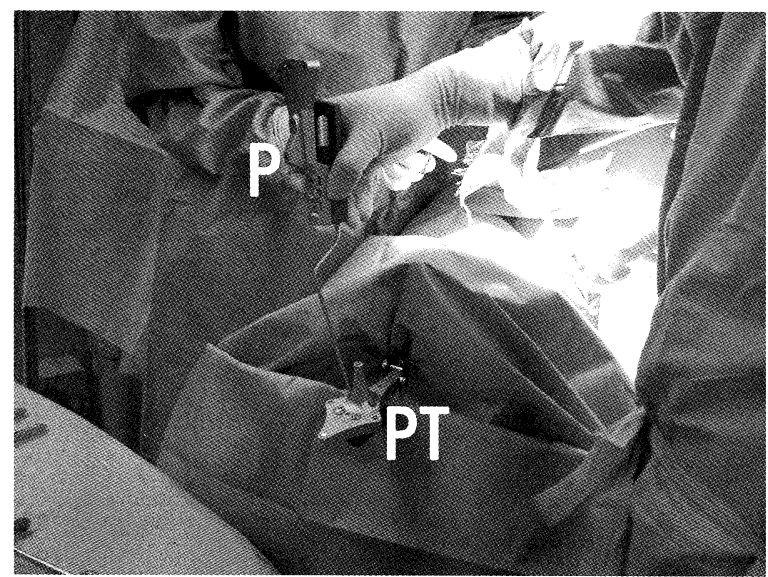

Fig. 4 Fixation of the patient tracker (PT). The tip of the pointer $(\mathrm{P})$ was confirmed to be at the site of the patient tracker.

images were constructed. On February 16, 2005, under general anesthesia, the maxillary cyst was resected, and the right maxillary second premolar and first molar were extracted. After induction of general anesthesia, a headband and patient tracker that provides a patient's positional information as infrared rays were fixed on the head of the patient, and the splint used in CT was applied again to the maxilla (Fig. 3, 4). Headband was put from the inferior of external occipital protuberance to the tempora and the stabilizer made of the felt was set under the connector, so that patient tracker should not shift during oper-

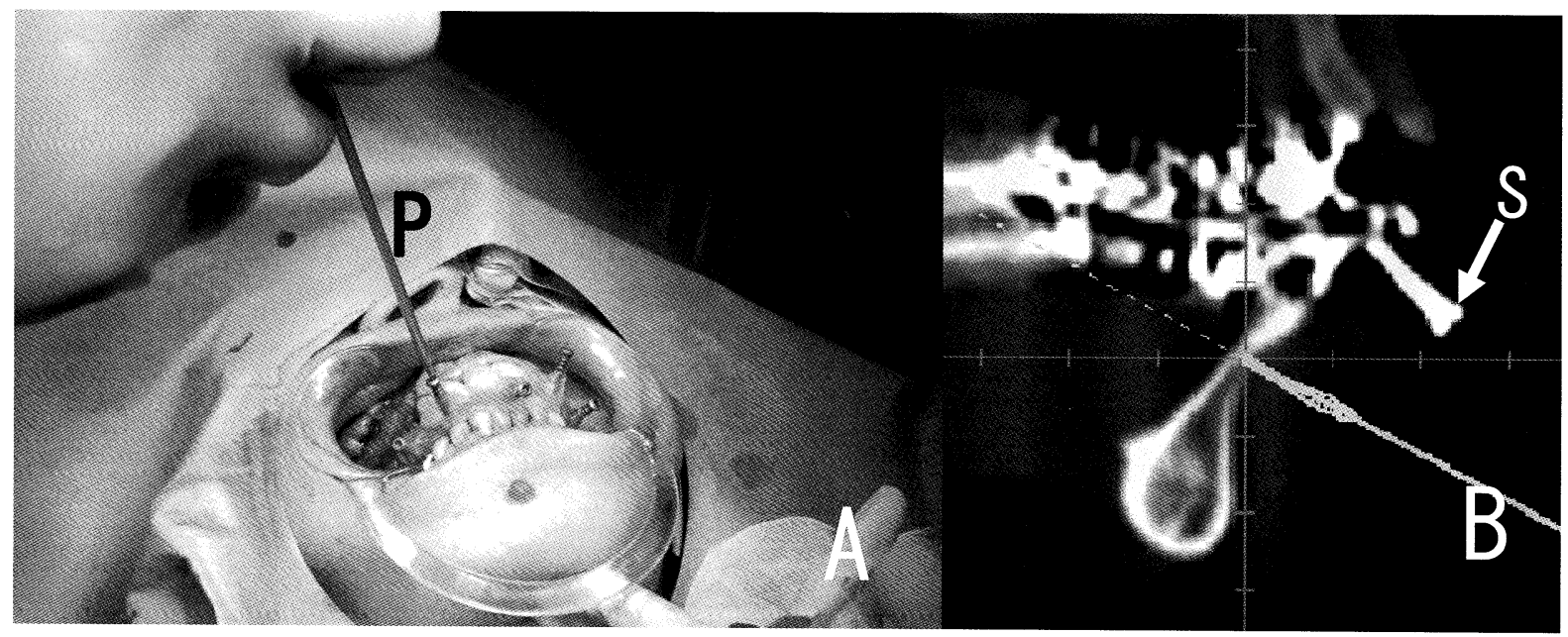

Fig. 5 Registration on the workstation. A: The splint used in CT scanning of the maxilla was applied again, and the 5 reference points were transmitted one after another to the workstation. B: the image indicated the titanium screw (S) as non-invasive registration point. Artifact was not seen at all. 


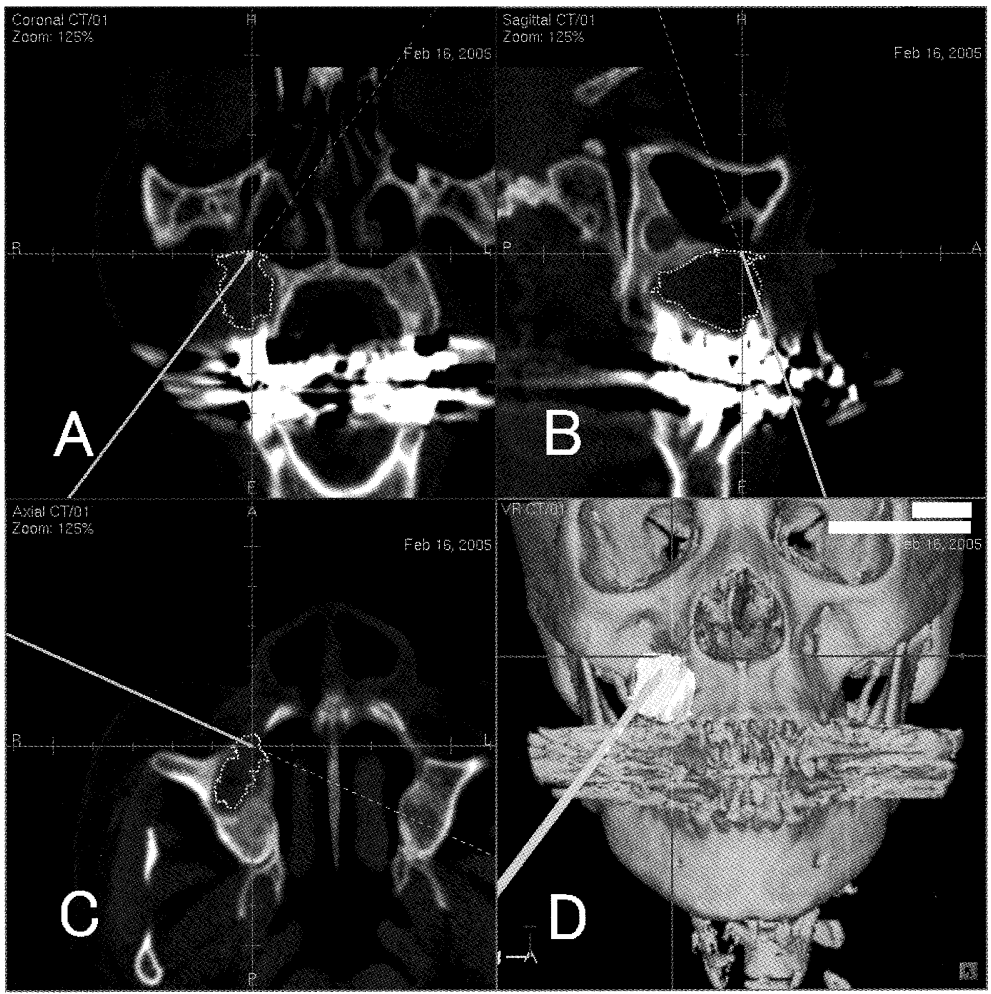

Fig. 6 Navigation in the area close to the nasal mucosa. A: metopic image, B: sagittal image, C: horizontal image, D: 3-dimensional image. The positional relationship between the cyst resection cavity and nasal cavity was instantly visualized as an image.

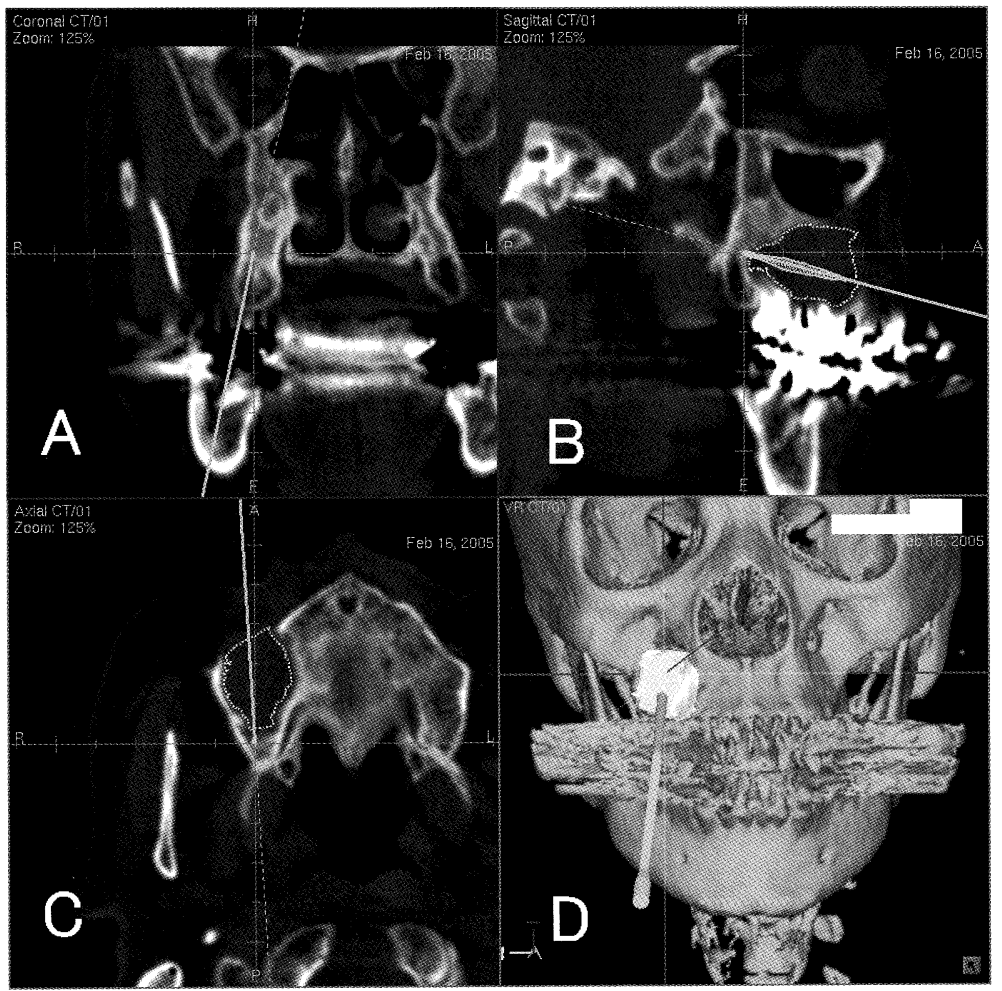

Fig. 7 Navigation in the area surrounding the root of the second molar. A: metopic image, B. sagittal image, C: horizontal image, and D: 3-dimensional image. The distance between the virtual and real spaces on the X-, Y-, and Z-axes was less than $1.0 \mathrm{~mm}$. 
ation. Five reference points at the deepest site of the depression of each screw head were transmitted one after another to the workstation using the special infrared transmission pointer, and registration was completed (Fig. 5A, B). Accuracy in the operation field was calculated on the workstation and estimated as $0.5 \mathrm{~mm}$ or less. Subsequently, the splint was removed, and operation was initiated. Using this system for the bone surface of the cyst wall and the wound surface during dissection and after removal, the cyst could be safely resected while confirming anatomical areas. In particular, objective confirmation of the portion of the cyst wall close to the nasal mucosa (Fig. 6) and the complex portion of the lesion surrounding the dental root of the second molar (Fig. 7) was very useful in this patient. These important anatomical points were recorded on the workstation. The accuracy on the $\mathrm{X}$-, Y-, Z-axes, discrepancy between the virtual and real

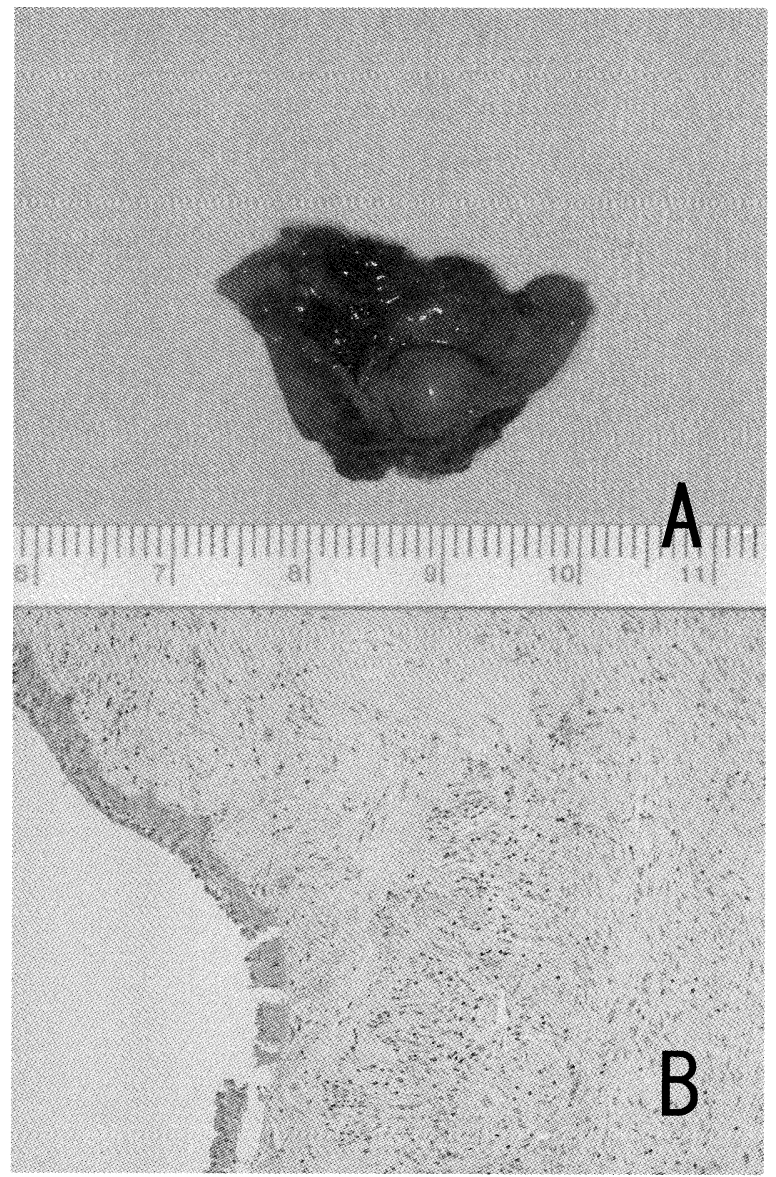

Fig. 8 A: resected specimen B: histopathological image (HE staining, $\times 33$ ). space, was calculated on the printed out image using a supplemental ruler. The resected specimen was cystic soft tissue composed of edematous thickened walls and markedly fragile in the portion in contact with the dental root (Fig. 8A). For histopathological findings, a cyst-like structure lined with partially detached pseudostratified ciliated epithelium or stratified squamous epithelium was observed. The cyst wall showed inflammatory cell infiltration, fibrous connective tissue accompanied by cholesterin deposition and granulation tissue (Fig. 8B). Detailed examination of serial sections showed no findings suggesting malignancy. Histopathological diagnosis of postoperative maxillary cyst was made from these findings.

\section{Discussion}

The surgical navigation system is a tool that allows the visualization of surgical manipulation areas as 3-dimensional real-time images by registration between the virtual space constructed by preoperative plain CT and the real space during operation as computer graphics. Navigation surgery has been developed for operations such as tumor resection in neurosurgery and total hip arthroplasty in orthopedic surgery, and has been applied to and widely used in these fields ${ }^{1)-5}$. However, applications in the maxillofacial/oral field have rarely been seen in Japan.

The establishment of reference points is indispensable for navigation. In general, anatomical landmarks as immovable points such as the subnasal point, alinasal base, medial and lateral eye angles, and maxillary incisor are used in the fields of neurosurgery and otolaryngology. In other methods, before CT scanning, artificial landmarks detectable on images are applied by taping on the shaved scalp, or metal screws are invasively fixed on the bone surface. However, these anatomical or artificial landmarks present problems of navigation accuracy and invasiveness. To overcome these problems in the application of navigation to the maxillofacial field, the registration system using reference points on the occlusal splint has been reported to be very useful ${ }^{677}$. In addition, for the maintenance of accurate navigation, the accurate fixation/maintenance of the 3-dimensional positional relationship between the patient's tracker and the head is necessary ${ }^{8 / 9)}$. In addition, navigation accuracy increases in parallel to the number of registered reference points and their immobility. Data using occlusal splints in the Department of Oral and Maxillo-facial Surgery, School of Dentistry, University of 
Freiburg, showed that the establishment of 4 reference points allows surgical navigation with an accuracy of 1.0 $\mathrm{mm}$ or less ${ }^{67)(10)}$. In this patient, the time required for the setting of this system in the operation room was only 20 minutes, and the accuracy in the field of operation (distance between the virtual and real spaces on the X-, Y-, and Z-axes) calculated by the workstation was $1.0 \mathrm{~mm}$ or less. This new registration system is advanced in assumption that the position of splint is exactly reproduced. In the future research, it is indispensable to confirm this reproducibility.

In this patient, this system was used for the bone surface of the cyst wall and the wound surface during dissection and after resection, and safe resection of the cyst while confirming anatomical areas was possible. In particular, the greatest advantage of this system in this patient was that the portion of the cyst wall close to the nasal mucosa and the complex portion of the lesion surrounding the root of the second molar could be confirmed in real-time.

Accurate evaluation of anatomical relationships is indispensable for safe and accurate surgery. In maxillofacial surgery, which often depends on the empirical decisions and skills of surgeons, this navigation system is expected to become a cornerstone to facilitate the safe, accurate, and objective decision making of areas for surgical manipulation, direction of instruments, and the amount of tissue resection. In addition, since surgical approaches via small incisions are possible, this method is less invasive than conventional surgery, and may become useful in maxillofacial surgery aiming at aesthetic and functional preservation. Moreover, this system allows recording of evidencebased surgery and can provide objective facts in medical suits and disclosure of medical records that have become more frequent in recent years. Since anatomical and surgical manipulation areas in actual patients can be visually recognized instantly, this system may also develop into a useful education tool for students and young surgeon/medical workers.

At present, this surgical navigation system in the maxillofacial field can be applied only to the maxillary bone. For the future wide-spread use of this system in the maxillofacial field, its application should be expanded to the mandibular area where the fixation/maintenance of the positional relationship with the head is difficult. Further studies on various oral diseases are necessary to evaluate the usefulness of this new registration system using removable splint.

\section{References}

1) Hayashi N, Kurimoto M, Hirashima Y, et al. Efficacy of navigation in skull base surgery using composite computer graphics of magnetic resonance and computed tomography images. Neuro Med Chir (Tokyo) 2001; 41: 335-339.

2) Perlick L, Bathis H, Tingart M, Perlick C, Grifka J. Navigation in total-knee arthroplasty: CT-based implantation compared with the conventional technique. Acta Orthop Scand 2004; 75: 464-470.

3) Stipcak V, Stoklas J. Implantation of a non-cemented acetabulum with the use of a navigation system. Acta Chir Orthop Traumatol Cech 2004; 71: 288-291.

4) Anon JB, Klimek L, Mosges R, Zinreich J. Computerassisted endoscopic sinus surgery; An international review. Otolaryngol Clin North Am 1997; 30: 389-401.

5) Klimek L, Wenzel M, Mosges R. Computer-assisted orbital surgery. Ophthalmic Surg 1993; 24: 411-417.

6) Schramm A, Gellrich NC, Naumann S, et al. Non-invasive referencing in computer assisted surgery. Comput Biol Med 1999(suppl); 37: 644.

7) Schramm A, Gellrich NC, Schimming R, et al. Ruchnergestützte insertion von zygomatikumimplantaten (Brånemark-system) nach ablativer tumorchirurgie. Mund Kiefer Gesichtschir 2000; 4: 292-295.

8) Schmelzeisen R, Gellrich NC, Schramm A, Otten JE. Navigation-guided resection of temporomandibular joint ankylosis promotes safety in skull base surgery. J Oral Maxillofac Surg 2002; 60: 1275-1283.

9) Gellrich NC, Schramm A, Hammer B, et al. Computerassisted reconstruction of unilateral posttraumatic orbital deformities. J Plast Reconstr Surg 2002; 110: 1417-1429.

10) Wada S, Furuta I, Gellrich NC, Schramm A, Schmelzeisen R. Development of navigation system for maxillofacial surgery. Hosp Dent (Tokyo) 2004; 16: 97-100. 